\title{
CBC PROGRAMMES IMPACT IN NORTHWEST NUTS II REGION OF BULGARIA IN THE PERIOD 2007-2013
}

\author{
Veselina Georgieva*1 \\ * Bulgarian Association of the EU Programmes Consultants (BAKEP)
}

\begin{abstract}
The purpose of the paper is to study the impact of the cross-border cooperation programmes in the Northwest Nuts II Region of Bulgaria in the period 2007-2013. The results to be achieved with the study is to assess the effectiveness of EU CBC programmes in one of the most backward EU NUTS II region and to identify the positive and negative effects of various interventions realized with EU funding. In addition, the study evaluates the outputs and results of different types of measures, incl. hard and soft projects and their influence on the local economic and sustainable development as well as their contribution to achieving the objectives of EU cohesion policy in the observed programming period. The conclusion made in the paper is directly related to the cross-border and transnational cooperation with specific focus on particular geographical area. Best practices and challenges are also identified and related to the needs and objectives of the target region in the new programming period 2014-2020.
\end{abstract}

Key words: CBC, Programmes, Impact, NUTS II Region

\section{Introduction}

Although subject to advanced processes of integration, the territory of the European Union does not yet represent a fully functional unit. The existence of deferring administrative systems creates barriers to the balanced development of different European regions. Border areas constitute approximately $40 \%$ of the EU's territory and are home to one third of its 500 million citizens. These areas are often economically weak, with relatively underdeveloped infrastructure and significantly higher unemployment in

${ }^{1}$ Correspondence to: v.georgieva@proactive-team.com 
comparison to more central regions within their respective states (Bohm 2014; Тошић и Живановић, 2012; Ђерчан и др., 2011;).

In order to address these large disproportions among regions and to make the most backward cross border territories more advanced and competitive, the cross border cooperation was developedas a Community initiative in 1990. Ten years later, the so called INTERREG was reorganised as a formal "objective" of European Cohesion Policy.

European Cross-border cooperation aims to tackle common challenges identified jointly in the border regions and to exploit the untapped growth potential in border areas, while enhancing the cooperation process for the purpose of the overall harmonious development of the Union (http:/ / ec.europa.eu/regional_ policy/en/policy/cooperation/european-territorial/cross-border/\#1).

In the past 25 years, the European Union has launched many cross border cooperation programmes, some of them implemented simultaneously for one and the same region because of the actual border with more than one neighbouring country. Although much progress has been made, difficulties remain in many areas, such as infrastructure, unemployment, healthcare, etc.

\section{Goal, methods and working hypothesis}

The present paper will focus on the role of the two INTERREG programmes implemented in the period 2007-2013 in the Northwest Nuts II Region of Bulgaria. It will include a brief overview of the objectives, priorities and financial resources allocated as well as a summary of projects implemented by types of measures. The main goal is to identify the positive and negative effects of various interventions realized with EU INTERREG programmes funding and to evaluate how the various types of measures (hard and soft) influenced the local economic and sustainable development.

The reason the Northwest Nuts II Region of Bulgaria was selected for this study is that according to EUROSTAT and various analysis this is the most backward region in the European Union. The Northwest Region of Bulgaria has a common border with 1) the Southwest Nuts II Region of Romania which is also suffering considerable economic and social challenges, and 2) the Southern and Eastern Serbia with similar socio-economic constraints. The three NUTS II territories in Bulgaria, Romania and Serbia are characterized by a wide geographical and environmental diversity. In the CBC programming documents (BULGARIA - SERBIA IPA CROSS-BORDER PROGRAMME 
2007-2013 and ROMANIA - BULGARIA CROSS-BORDER COOPERATION PROGRAMME 2007-2013), it is considered that the strongest asset of these territories is their geographical location in the centre of the Balkan Peninsula on the Danube River with its strong potential for a large variety of applications. Owing to this assumption, the geographical location is "... underestimated when evaluating the factors of socio-economic, cultural and political development... and it is considered to be the major source of resources and wealth." (K. Stoychev, Problems of the Geo-Economic Transition of the Balkan States, 2011).

The following working hypothesis will be verified: Because of the socioeconomic characteristics ofthe Northwest Region of Bulgaria and the similar priorities and measures in both cross border cooperation programmes implemented in the period 2007-2013, the EU INTERREG spending in this region should have the highest impact and the results of the implemented cross border project should have immediate effect on local economy and community wealth.

Mainly quantitative research methods with some qualitative elementsare applied to verify this hypothesis. The positive and negative effects of various interventions realized with EU funding within the $\mathrm{CBC}$ programmes are analysed, more particularly by types of interventions and their overall effect on key statistical indicators such as GDP, Employment rate and Investments in Research and Development activities (R\&D). These indicators are selected for the analysis for two reasons: first, because they are used to measure the progress in achieving the objectives of Europe 2020 Agenda; and second, because the development policies need to attract higher quality, more embedded investments ${ }^{2}$ which are measured mainly with the selected statistical indicators.

\section{Theoretical background}

The Nomenclature of territorial units for statistics, abbreviated NUTS (from the French version Nomenclature des Unités Territoriales Statistiques) is a geographical nomenclature subdividing the economic territory of the European Union (EU) into regions at three different levels (NUTS 1, 2 and 3 respectively, moving from larger to smaller territorial units).

The NUTS is based on Regulation (EC) No 1059/2003 of the European Parliament and of the Council of 26 May 2003 on the establishment of a common classification of territorial units for statistics (NUTS), which is regularly updated.

${ }^{2}$ Peter Sunley, Urban and Regional Growth (2002) 
NUTS 2 are the basic regions for the application of regional policies and for the purposes of cross border cooperation part or their entire territory forms another territorial structure - Euroregion.

The Association of European Border regions (ABER) sets the following criteria for the identification of Euroregions (Lochman 2009):

- An association of local and regional authorities on either side of the national border;

- A cross border association with a permanent secretariat and a technical and administrative team with its own resources;

- In the private sector, based on non-profit-making associations or foundations on either side of the border in accordance with the respective national law in force;

- In the public sector, based on inter-state agreements, dealing among other things, with the participation of territorial authorities.

In the case of INTERREG cooperation programmes, our target territory (the Northwest NUTS II Region of Bulgaria) implements the EU funded measures as part of a Euroregion since both cross border cooperation programmes can be determined as cross border associations with a permanent secretariat and a technical and administrative team with their own resources.

\section{Socio-economic characteristics of Northwest NUTS II Region of Bulgaria}

The Northwest Region includes 5 administrative units of NUTS III level - Vidin (BG311), Montana (BG312), Vratsa (BG313), Pleven (BG314) and Lovech (BG315) and 51 municipalities (LAU 1).

The National Strategy for Regional Development 2012-2022 determines as important characteristics and potential for development of the Northwest region the following:

- The favourable geographical location, preserved natural resources and cultural heritage are endowments for development of tourism and increasing the potential of tourist industry;

- The quality of environment increases the attractiveness of the territory for living, business and tourism; 
- The transport infrastructure - Trans European Transport Corridors 4 and 7 (the Danube River), ports and ferry complexes, multimodal transport and the second bridge over the river at Vidin - Calafat are potentials for business development and tourism, as well as for effective cross-border cooperation;

- The Danube River has serious transport and energy potential and as a water resource is essential to the economic development of the region;

- Availability of quality and efficient use of land resources.



Figure 1 - Administrative units of NUTS III level in Bulgaria Source: http://www.wikiwand.com/it/Nomenclatura_delle_Unit\%C3\%A0_ Territoriali_per_le_Statistiche_della_Bulgaria

The so defined characteristics and potentials for development are taken into account in the two relevant for the region CBC programmes in the period 2007-2013 in terms of objectives and results to be achieved and measures and projects to be implemented. in Table 1.

The main socio-economic characteristics of the region are presented 
Table 1 - Socio-economic characteristics of Northwest (Severozapaden) NUTS II Region of Bulgaria

\begin{tabular}{|c|c|c|c|c|c|c|c|c|}
\hline  & 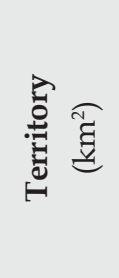 & 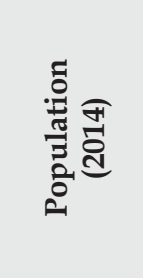 & 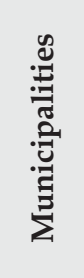 & की & $\sum_{0}^{\infty}$ & 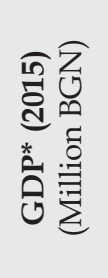 & 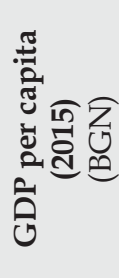 & 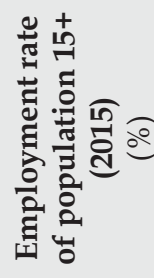 \\
\hline Bulgaria & 111.002 & 7.153.784 & 264 & 5.302 & 257 & 83.612 & 11.574 & 49,10 \\
\hline Northwest & 19.070 & 797.142 & 51 & 646 & 45 & 5.932 & 7.381 & 41,00 \\
\hline Vidin & 3.033 & 93.361 & 11 & 142 & 7 & 570 & 6.034 & 40,90 \\
\hline Vratsa & 3.620 & 175.169 & 10 & 123 & 8 & 1.678 & 9.494 & 37,50 \\
\hline Lovech & 4.129 & 133.513 & 8 & 128 & 8 & 1.027 & 7.635 & 39,00 \\
\hline Montana & 3.636 & 139.350 & 11 & 130 & 8 & 929 & 6.611 & 39,30 \\
\hline Pleven & 4.653 & 255.749 & 11 & 123 & 14 & 1.728 & 6.710 & 45,20 \\
\hline$\% \mathrm{NW} / \mathrm{BG}$ & $17 \%$ & $11 \%$ & $19 \%$ & $12 \%$ & $18 \%$ & $7 \%$ & $64 \%$ & \\
\hline
\end{tabular}

Source: National Statistical Institute

\section{INTERREG programmes in the Northwest NUTS II Region of Bulgaria for the period 2007-2013}

Of the 60 EU cooperation programmes in total for the period 2007-2013 with an allocation of EUR 6 billion involved in a wide variety of activities linked to the maturity of border cooperation, 2 with a total budget of approximately MEUR 229 (MEUR 11,6 for the CBC programme Bulgaria - Serbia and MEUR 217,8 for the CBC programme Romania - Bulgaria) are designed for some of the NUTS III administrative units in the Northwest region of Bulgaria. More particularly, the eligible districts that fall in the scope of the two CBC programmes and that are part of the Northwest region of Bulgaria are as follows:

- CBC Romania - Bulgaria programme - districts Vidin, Vratsa, Montana and Pleven;

- CBC Bulgaria - Serbia programme -districts of Vidin and Montana.

It should be noted that from all NUTS III administrative units that form the entire territory of the target region, only the district of Lovech is not included as eligible in any of the two CBC programmes. 
Table 2 - Summary of projects in the Northwest NUTS II Region of Bulgaria funded within CBC Romania - Bulgaria Programme

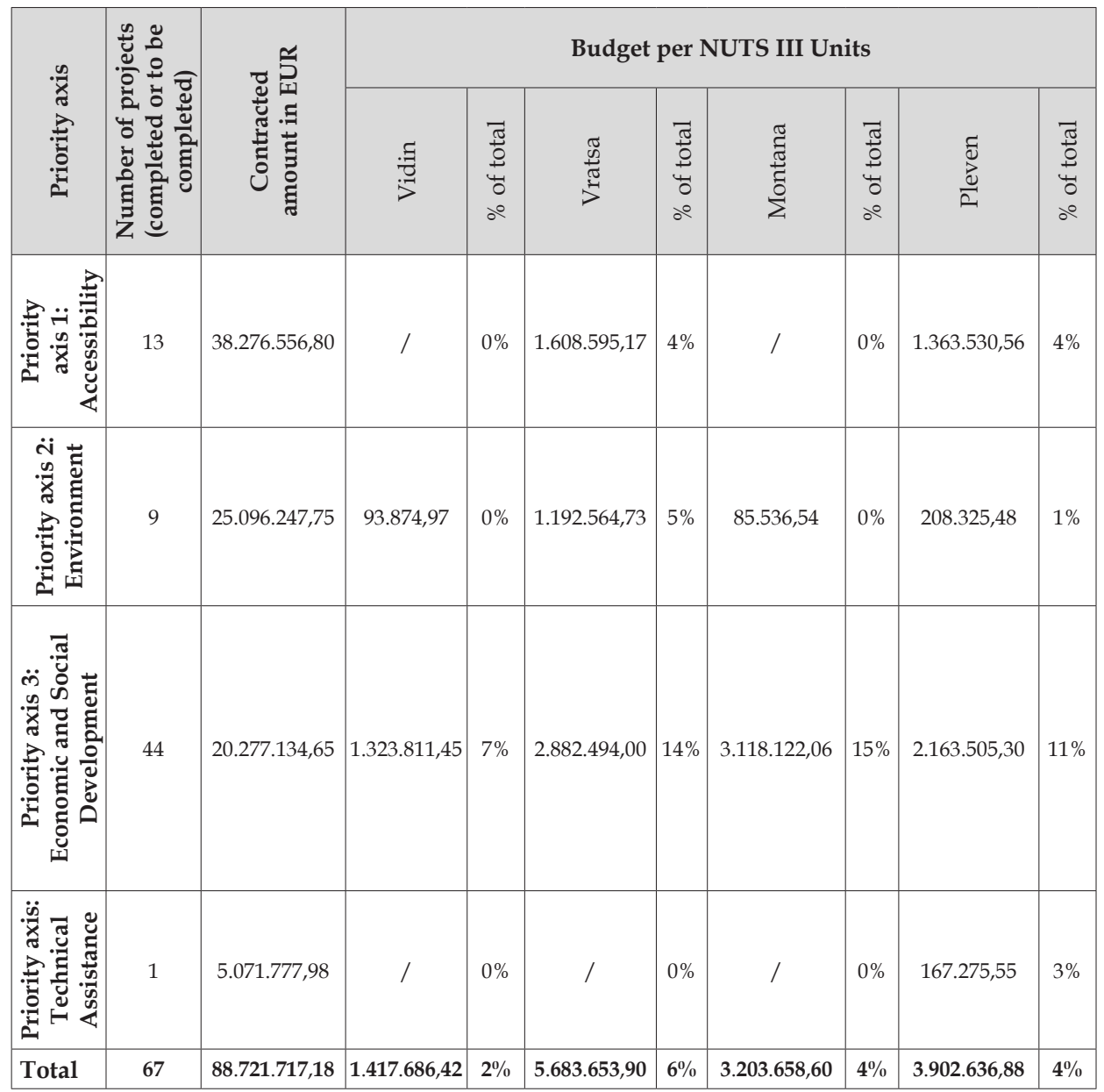

Source: http:/ / www.cbcromaniabulgaria.eu/index.php?page=proiecte-lista

Notes:

1. The contracted amount is equal to that of the Subsidy contract which is signed with beneficiaries that might be outside the target area;

2. The share of the total budget per district is calculated as ratio: budget per NUTS III unit / total contracted amount.

Within the several calls for project proposals that were launched a significant number of projects were contracted in the eligible administrative units that are summarized in Table 2 and Table 3. 
Table 3 - Summary of projects in the Northwest NUTS II Region of Bulgaria funded within CBC Bulgaria - Serbia Programme

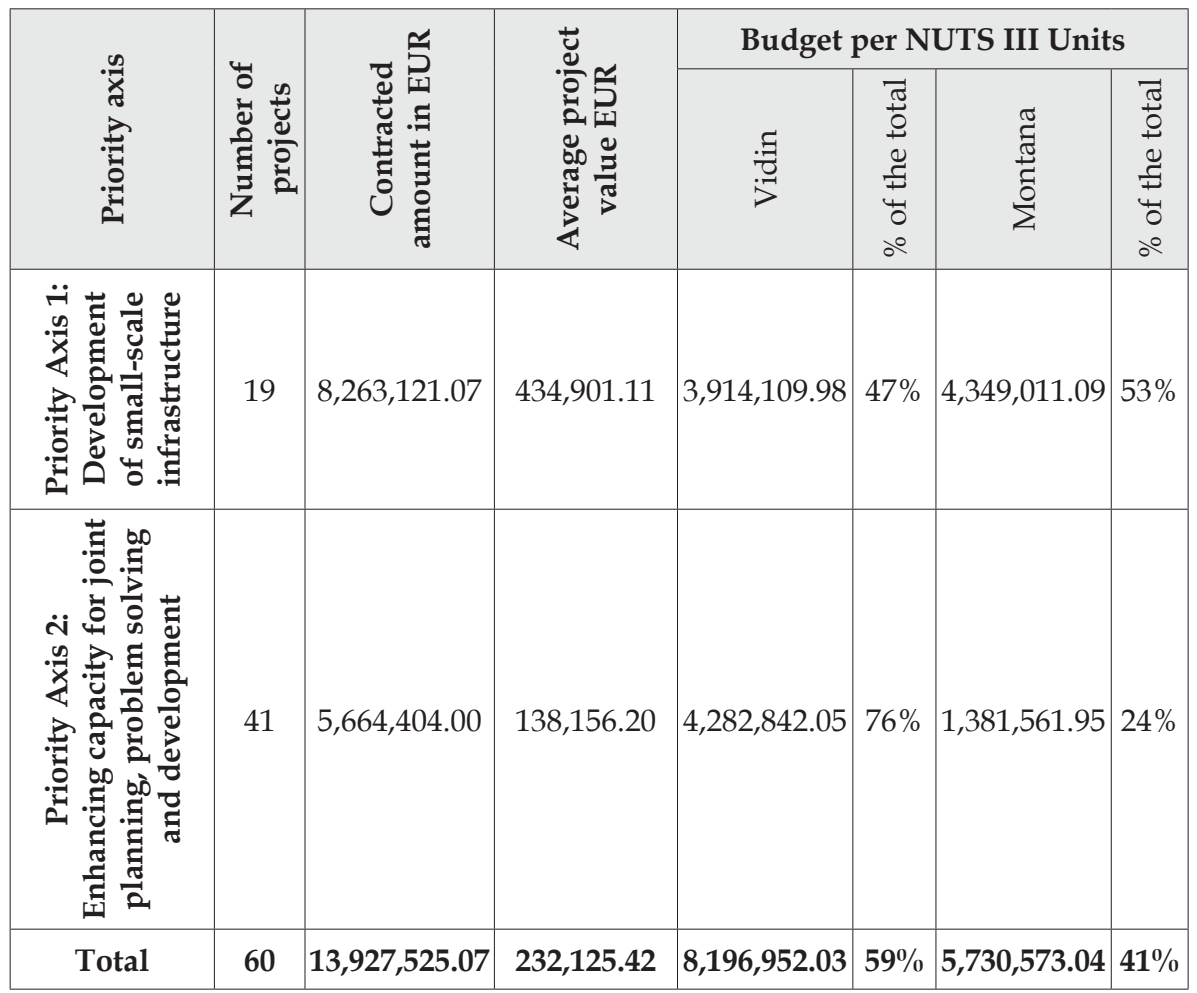

Source: http:/ /07-13.ipacbc-bgrs.eu/ page.php?c=59

Notes:

1. There is no information about budget allocations per NUTS III units. Therefore, the budget allocated to NUTS III administrative units is calculated on the basis of average project budget by priority axis;

2. The contracted amount is equal to that of the overall project budget allocated to all project beneficiaries (some might be outside the target area);

3. The share of the total budget per district is calculated as ratio: budget per NUTS III unit / total contracted amount. 


\section{Contribution of the two CBC programmes to the performance of selected key statistical indicators}

Before comparing the basic values (2007) of the selected key statistical indicators listed above with their current values, it is important to emphasise that the two CBC programmes designed for the target region can be considered as supplementary to the other EU grant financing which comes mostly through the national operational programmes (OPs).

According to the ex-post evaluation of the Regional Development Plan of the Northwest NUTS II Region of Bulgaria for the period 2007-2013, the total amount of allocated funding from the OPs is about 1,3 billion Euro. The largest share of these funds are used for development of the transport, technical and environmental infrastructure $(60 \%)$, followed by investments for enhancing the competitiveness of regional economy $(27 \%)$ and improving the attractiveness of the living environment and living conditions in settlements (13\%).

The overall effect of all these public funds by NUTS III units in the target area can be seen in Table 3 .

Table 4 - Comparison of selected key statistical indicators

\begin{tabular}{|l|c|c|c|c|c|c|c|c|c|}
\hline \multirow{2}{*}{$\begin{array}{c}\text { NUTS } \\
\text { Units/year }\end{array}$} & \multicolumn{3}{|c|}{ GDP (million EUR) } & \multicolumn{3}{c|}{$\begin{array}{c}\text { Employment \% } \\
\text { Population 15-64 }\end{array}$} & \multicolumn{3}{c|}{$\begin{array}{c}\text { Investments in R\&D } \\
\text { (thousands EUR) }\end{array}$} \\
\cline { 2 - 11 } & $\mathbf{2 0 1 0}$ & $\mathbf{2 0 1 2}$ & $\mathbf{2 0 1 4}$ & $\mathbf{2 0 1 0}$ & $\mathbf{2 0 1 2}$ & $\mathbf{2 0 1 4}$ & $\mathbf{2 0 1 0}$ & $\mathbf{2 0 1 2}$ & $\mathbf{2 0 1 4}$ \\
\hline $\begin{array}{l}\text { NUTS II } \\
\text { Northwest region }\end{array}$ & 2.750 & 2.960 & 3.032 & 54,9 & 54,4 & 56,1 & 996 & 1.481 & 1.922 \\
\hline Vidin & 280 & 280 & 291 & 48,7 & 52,2 & 55,3 & $/$ & 266 & $/$ \\
\hline Montana & 425 & 460 & 475 & 55,4 & 53,3 & 55,9 & $/$ & $/$ & $/$ \\
\hline Vratsa & 785 & 866 & 858 & 58,1 & 57,9 & $64 ., 4$ & $/$ & $/$ & 380 \\
\hline Pleven & 796 & 852 & 883 & 52,4 & 55,5 & 58,0 & 1.627 & 1.949 & 3.050 \\
\hline Lovech & 464 & 502 & 525 & 59,8 & 52,9 & 51,0 & 1.361 & 2.229 & 2.336 \\
\hline
\end{tabular}

As it was pointed, the two CBC programmes are supplementary because their contribution to the overall public funding is 102,6 MEUR or $14 \%^{3}$. However, we should not forget some important facts such as: 1) more than

${ }^{3}$ Calculated on the basis of total contracted amount. 
half of the projects are not completed yet; 2) the contracted amount is usually not fully spent because of savings as a result of public procurement procedures or financial corrections because of irregularities; and 3) only a part of the total contracted amount comes to the target region because not all project partners are from the respective NUTS III unit. Therefore, the actual financial contribution of INTERREG programmes is no more than a half (or even less) of the initially contracted amount.

\section{Conclusion}

The analysis shows that the overall public financial support for the Northwest NUTS II Region of Bulgaria has led to improvement of the selected statistical indicators and the CBC programmes have also their input to the present values of these indicators. Moreover, INTERREG initiatives are directly related to the specific problems and challenges of the Euroregion part of which is the respective NUTS II unit and their indirect effect is higher.

It should be also noted however, that the grant financing of various types of projects has positive as well as negative impact on the local economy and community behavior. The reason is that some projects which can be realized entirely or partially with financial instruments are still executed with grant support only. This leads to unjustified investments that consume the resources inefficiently and creates shortage in some segments of the regional socio-economic structure at the expense of others that might have greater needs and ought to receive public funds with priority.

On the other hand, as Michael Porter argues "...the places can create competitive advantage... and the local state can intervene to help identify the right opportunities" (Porter, 1990; Porter, 1995). Therefore, when designing the CBC programmes, the competent authorities must consider the NUTS II regions as part of a bigger Euroregion falling in the scope of the definitions given in this paper. Thus, these specific territories could benefit greater not only from INTERREG initiatives but also from mechanism such as European Group for Territorial Cooperation (EGTC) or European Economic Interests Group (EEIG) which can supplement efficiently the available EU, national or cross border financing. At the same time, because these mechanisms have their own investment strategies and act like local clusters, they inevitably will foster the regional integration in Europe and will increase the specialization of European regions (Krugman and Venables, 1990). 


\section{References}

Bohm, H. (2014). A Comparison of Governance forms for Cross Border Cooperation within the EU. Journal of Cross Border Studies, Vol. 9, pp. 36-50.

Bohm, H. (2015). Czech-Polish Borders: Comparison of the EU Funds for Cross Border Cooperation of Schools in Selected Euroregions. Cross Border review Book, Central European Service for Cross-Border Initiatives (CESCI), European Institute of Cross-Border Studies (Esztergom), pp. 59-73.

Krugman, P. and Venables, A. (1990). Integration and the Competitiveness of Peripheral Industry. In C. Bliss and J. Braga de Macedo (eds). Unity with Diversity in the European Economy. Cambridge University Press, pp. 56-75.

Porter, M. (1990). The Competitive Advantage of Nations. New York: Free Press

Porter, M. (1995). The Competitive Advantage of the Inner City. Harvard Business Review, Vol. 74 (May-June), pp. 55-71.

Stoychev, K. (2011). Problems of the Geo-Economic Transition of the Balkan States. Annuare De L'Universite De Sofia "St. Kliment Ohridski", Faculte De Geologie Et Geographie, Livre - Geographie, Tome 104.

Sunly, P. (2002). Urban and Regional Growth, A Companion to Economic Geography, pp. 187-201.

CBC Romania - Bulgaria Programme 2007-2013 https:// www.eufunds.bg/archive/documents/1259680547.pdf

CBC Bulgaria - Serbia Programme 2007-2013 https:// www.eufunds.bg/archive/documents/1259243714.pdf

INTERREG A - Cross-Border Cooperation http://ec.europa.eu/regional_ policy/en/policy/cooperation/european-territorial/cross-border/\#1

List of Projects, CBC Romania - Bulgaria Programme 2007-2013 http://www.cbcromaniabulgaria.eu/index.php?page=proiecte-lista

List of Projects, CBC Bulgaria - Serbia Programme 2007-2013 http:/ /07-13.ipacbc-bgrs.eu/ page.php?c=59

Map of Bulgaria's NUTS III units http:/ /www.wikiwand.com/it/Nomenclatura delle_Unit\%C3\%A0_Territoriali_per_le_Statistiche_della_Bulgaria

National Statistical Institute http:/ / www.nsi.bg/ 
NUTS - Nomenclature of Territorial Units for Statistics http://ec.europa.eu/eurostat/web/nuts/overview

Results of the Ex-post Evaluation of the Implementation of the Norwest NUTS II Region Regional Development Plan for the Period 2007-2013 http:/ / www.mrrb.government.bg/?controller=articles\&id=6568

Ђерчан, Б., Лукић, Т. и Бубало-Живковић, М. (2011). Регионални значај, проблеми и потенцијали пограничног подручја Срема. Зборник радова - Географски факултет Универзитета у Београду, 59, 131-156.

Тошић, Б. и Живановић, 3. (2012). Просторна сарадња Србије и Бугарске. Зборник радова - Географски факултет Универзитета у Београду, 60, 49-66. 